International Journal of Canadian Studies

Revue internationale d'études canadiennes

INTERNATIONAL JOURNAL OF CANADIAN STUDIES

\title{
Convergence and Divergence in United States and Canadian Cuba Policy Post-1959: A Triangular Comparative Analysis
}

\section{Raúl Rodríguez Rodríguez}

Numéro 37, 2008

Canadian Challenges

Les défis canadiens

URI : https://id.erudit.org/iderudit/040797ar

DOI : https://doi.org/10.7202/040797ar

Aller au sommaire du numéro

Éditeur(s)

Conseil international d'études canadiennes

ISSN

1180-3991 (imprimé)

Découvrir la revue

Citer cet article

Rodríguez, R. R. (2008). Convergence and Divergence in United States and Canadian Cuba Policy Post-1959: A Triangular Comparative Analysis. International Journal of Canadian Studies / Revue internationale d'études canadiennes, (37), 115-138. https://doi.org/10.7202/040797ar

\section{Résumé de l'article}

Le principal objectif de cet article consiste à examiner la convergence et la divergence de la politique de ces deux pays d'Amérique du Nord envers Cuba. $\mathrm{Au}$ cours des 49 dernières années, il y a eu une foule d'événements importants et spectaculaires sur les plans économique, politique, militaire et socio-culturel dans le monde qui ont eu une incidence sur cette relation triangulaire. Par conséquent, il vaudrait la peine de consacrer un texte beaucoup plus long même à la plus petite tentative d'examen de tous les aspects d'une période aussi longue. Cependant, un survol de la période postérieure à 1959 révèle une continuité remarquable dans la politique américaine à l'égard de Cuba. Le principal objectif des gouvernements américains qui se sont succédés, tant républicains que démocrates, a été de changer le régime en utilisant un arsenal complet de moyens secrets et déclarés tandis que la politique canadienne a divergé surtout du point de vue des moyens utilisés pour promouvoir les changements souhaités qui ramèneraient Cuba au sein des pays capitalistes occidentaux. Cet article résulte surtout d'une étude des premières années de la révolution cubaine, de 1959 à 1962, au cours desquelles il s'est produit un grand nombre d'événements qui ont façonné et transformé la société cubaine. Ces événements ont donné le ton pour les années à venir dans le contexte de l'ordre des relations internationales qui a prévalu par suite de la Deuxième guerre mondiale et de la guerre froide.
Tous droits réservés @ Conseil international d'études canadiennes, 2008
Ce document est protégé par la loi sur le droit d'auteur. L’utilisation des services d'Érudit (y compris la reproduction) est assujettie à sa politique d'utilisation que vous pouvez consulter en ligne.

https://apropos.erudit.org/fr/usagers/politique-dutilisation/ 


\title{
Raúl Rodríguez Rodríguez
}

\section{Convergence and Divergence in United States and Canadian Cuba Policy Post-1959: A Triangular Comparative Analysis}

\begin{abstract}
The main objective of this article is to explore the convergence and divergence in both of these North American nations' Cuba policy. The last 49 years have been full of important and dramatic economic, political, military, and socio-cultural events worldwide that have had an impact on this triangular relationship. Therefore, even the smallest attempt at covering all aspects over such a long period would be worthy of a much lengthier piece of writing. However, an overview of the post-1959 period reveals a remarkable continuity in American Cuba policy. The main objective of successive United States governments, both Republican and Democrat, has been regime change by using a full arsenal of overt and covert means, while Canadian policy has diverged mostly in terms of the means to promote the desired changes that would bring Cuba back to the pattern of Western socio-economic capitalist formation. This article is mainly the result of a study of the initial years of the Cuban revolution, from 1959 to 1962, that were full of defining and transformational events. These events set the tone for the years to come against the backdrop of the prevailing order of international relations resulting from the Second World War and the Cold War.
\end{abstract}

\section{Résumé}

Le principal objectif de cet article consiste à examiner la convergence et la divergence de la politique de ces deux pays d'Amérique du Nord envers Cuba. Au cours des 49 dernières années, il y a eu une foule d'événements importants et spectaculaires sur les plans économique, politique, militaire et socio-culturel dans le monde qui ont eu une incidence sur cette relation triangulaire. Par conséquent, il vaudrait la peine de consacrer un texte beaucoup plus long même à la plus petite tentative d'examen de tous les aspects d'une période aussi longue. Cependant, un survol de la période postérieure à 1959 révèle une continuité remarquable dans la politique américaine à l'égard de Cuba. Le principal objectif des gouvernements américains qui se sont succédés, tant républicains que démocrates, a été de changer le régime en utilisant un arsenal complet de moyens secrets et déclarés tandis que la politique canadienne a divergé surtout du point de vue des moyens utilisés pour promouvoir les changements souhaités qui ramèneraient Cuba au sein des pays capitalistes occidentaux. Cet article résulte surtout d'une étude des premières années de la révolution cubaine, de 1959 à 1962, au cours desquelles il s'est produit un grand nombre d'événements qui ont façonné et transformé la société cubaine. Ces 
événements ont donné le ton pour les années à venir dans le contexte de l'ordre des relations internationales qui a prévalu par suite de la Deuxième guerre mondiale et de la guerre froide.

The year 1959 became a turning point in the history of the Cuban republic; the triumph of the Cuban Revolution marked the beginning of a process of profound socio-economic and political transformations on the island nation that were translated into a clean break with the socio-economic and political pattern prevailing in the rest of the western hemisphere, which had long been the hegemonic domain of the United States. Cuba's national social revolution was based on a strong and swift structural transformation that began incorporating new property and class relations and that limited the private capitalist accumulation.

Consequently, the initial reaction of the United States government, with the support of the Cuban propertied class, was to resort to economic, political, and diplomatic pressure, and internal subversion. Both the Eisenhower and Kennedy administrations overtly tried very hard, turning to NATO and the Organization of American States, to form a multilateral coalition to enforce economic sanctions and to promote the political and diplomatic isolation of a new Cuban government. Both US administrations used covert political pressure on allies such as Japan, the United Kingdom, and Canada ${ }^{1}$ to force support for such punitive actions.

Therefore, the extraterritorial dimension of US policy toward Cuba since the early months of the revolution lead the new Cuban government to become involved in more than one triangular conflict with several international actors in different geographical areas. The main objective was to try to minimize the impact of these initial economic sanctions by looking to purchase machinery, spare parts, and other supplies that could not be acquired in the suddenly off-limits US market.

At that point in time, Cuba's relations with the two North American nations were totally asymmetrical; the island's relations with the United States and by extension its corporations had a strong historical and socio-cultural component, and the economic relations were that of heavy dependence, especially since 1902 . Canada had a small but solid presence, especially in the banking and insurance sector, and had only recently established political and diplomatic ties.

The nationalist positions advocated and promoted by the Cuban government soon after 1 January 1959; the island's economic, political, and socio-cultural relations with the United States; and the nature ${ }^{2}$ and dynamics of Canadian-American relations in the context of the Cold War as the prevailing post-Second World War order of international relations all became a great challenge to bilateral relations between Canada and Cuba, the main component of which was trade and financial relations. ${ }^{3}$ 
In this context, the triangular relationship appeared to reach a conflict stage as Cuban policy-makers sought to counteract the effects of the United States' reaction to the radicalization of the revolution that was to initially impose an economic embargo. The Cuban government that emerged from the 1959 revolution tried to preserve and expand its links with Canada, since Canada's export-oriented economy was in a unique position to at least partially fill the void that the sudden suspension of trade with the Unites States created in terms of commercial exchange.

In terms of international relations, the Unites States and Canada were to reach the condition of complex interdependence regardless of the high asymmetry ${ }^{4}$ that characterized it. Another important factor to be taken into account is that the much-lauded largest bilateral relation must be framed in Cold War terms as the prevailing bipolar order of the international relations resulting from the Second World War.

Given Canada's great historical, cultural, social, political, defence, and security relations with the United States, it is worthy to note that although there was ideological convergence on the Cuba issue, it also brought to the forefront a historical divergence between the two North American neighbours. The three-way relation has evolved ever since and has reached the present in a triangle of tension and co-operation ${ }^{5}$ that has characterized the 49 years that have followed 1 January 1959.

\section{Canada-U.S. Relations in Context}

One side of the triangle, which is in no shape or form an equilateral one if one looks at the Cuba-US and the Cuba-Canada relationships, is the Canada-US side. Undoubtedly, Canada-US comparisons have long been subject to vigorous debate, not only in academia and in the realm of policy-making and practitioners, but also among everyday common individuals on both sides of the 49th parallel.

From an international relations perspective, it is safe to conclude that the relations between Canada and the United States since the end of the Second World War have evolved into a condition of complex interdependence in which non-state and transnational actors play an increasingly important role in shaping the economic, social, political, and military bilateral relation.

The extent of similarities and differences in values and belief systems, and their evolution over time, are extremely important, for they have found their expression in the foreign policy of both nation-states. Post-1959 Cuba policy is an example of how the two nations, while essentially converging within the Western pattern of civilization, also have important points of divergence. 
There are several arguments to support the case for important divergence between Canada and the United States. One argument contends that the variations in the prevailing value systems of the two countries may have more to do with their basic structural differences, which are basically derived from the foundation of both countries and the geographical space they occupy. However, as they have become more interdependent in the context of globalization, the formation of regional blocs and deeper North American integration - the structural differences - tend to disappear.

There is also a historical argument to provide that both countries are essentially different. Seymour Martin Lipset makes the stronger case for this: "Canada has been a more class aware, law-abiding, collectivity oriented, and pluralistic (group oriented) society than the United States and these fundamental distinctions stem largely from the events that divided British North America, the American Revolution."6

These basic differences have remained over time, as pollster Michael Adams ${ }^{7}$ claimed in his recent book. Canada and the United States are "fundamentally different" and "always have been," he argues: the two countries "were separated at birth, organized and governed differently." Adams suggests that the principles of both constitutions and nationbuilding diverge from the original intent.

Robert Bothwell also argues in favour of this historical argument to stress the divergence, between the two North American countries, and incorporates the socio-demographic and geographical aspects when comparing the early characteristics of both countries. He reminds us that in British North America, "the people were newer with shallower roots ... there was less land on which to settle, though there was plenty of rock and muskeg to accommodate wildlife." ${ }^{8}$ In Bothwell's correct appreciation, this contributed to the formation of a more compressed and constrained society in which a Tory conservative, collectivist pattern of life was rooted, making Canada essentially different from the United States.

As the United States made the economic blockade the cornerstone of its Cuba policy, and has subsequently tried to politically and diplomatically isolate Cuba so as to bring about internal change in the smaller nation, it also found divergent approaches as to how achieve the same objective in other Western nations - Canada, the United States' geographically closest ally, among them.

It must be made clear that both the American and the Canadian governments as representatives of their respective ruling classes shared similar ideological positions on the side of the Western alliance; therefore, differences in their approaches to dealing with the new government in Havana must be seen in terms of process rather than substance. In the words of one of Canada's most accomplished international relations scholars: "It 
is important to bear in mind, however, that countries can be united in a common purpose, but differ over tactics[;] it is in fact difference over tactics rather than ultimate ends [that] will continue to cause dispute between our two countries ... the way in which the United States-Canadian relations can be bruised by differences on an international issue has been more pleasantly revealed over the question of Cuba."

\section{The United States Trade Embargo and Canada-Cuba Relations, 1959-1962}

The rapid succession of events, actions, and responses in the escalating spiral that characterized the bilateral relations between Cuba and the United States soon after the initial months in 1959 had an impact on both Canada-US and Canada-Cuba relations.

The issue of trade had an important political implication. Trade relations specifically involved all three actors in a three-part connection that had very intense manifestations during the first couple of years that followed 1 January 1959. The evolution of events that unfolded soon after the first steps of the Moncada Program ${ }^{10}$ illustrate well the extent to which Canadian foreign policy-making process can be affected by the initiatives of American foreign policy, even when the primary target of the policy is not Canada itself.

Unites States government officials privately admitted that Cuba acted as an irritant between the two North American countries. " That the United States government envisioned Canada's position regarding the new government of Cuba as taking advantage "to make a quick buck," thus permitting Cuba to circumvent the embargo, was more a political concern than an economic problem. From Washington's standpoint, Canadian opposition to supporting the economic stranglehold of Cuba helped undermine their efforts to topple a government whose nationalist stance was affecting American economic interests; furthermore, it challenged American hegemony in the western hemisphere. In the view of the United States government, the left-leaning positions of the Cuban government could open the door to Communist penetration into what was considered by many the United States' backyard: Latin America and the Caribbean.

For Canada's conservative government, the option for independent Cuba policy was based on a sovereign position that was consistent with its tradition in favour of multilateral action, an international projection of a middle power with no imperialist or hegemonic designs over Latin America and the Caribbean. Canada's stance was also based in part on the genuine belief that embargo and isolation would push Cuba to the eastern side of the Cold War divide. Therein lies another significant point of divergence in both North American nations' approach to dealing with the new Cuban government after 1959. 
As the island's new leadership tried to construct a new model of economic and social development with nationalist and anti-imperialist characteristics, the trade and political relations with Canada constituted a much-needed short-term open door to the West, and the possibility of trying to construct a different kind of relationship than that of subordinated and dependent capitalism.

As the new Cuban government sought to reorient its foreign trade by increasing its trade relations with Canada, it met the opposition of the United States government. The triangle reached the conflict stage during the second year of the Cuban Revolution, in 1960.

The purpose of the following section is to take a closer look at the efforts of the United States government to secure the co-operation of the Canadian government, and by extension Canadian private enterprise, and at the Canadian responses regarding adhering to the provisions of the unilateral action of the United States to impose a trade embargo that would drastically restrict the trade flow to and from Cuba, thereby causing the collapse of the new Cuban government.

\section{An Overview of U.S.-Cuba Relations vis-à-vis Canada-Cuba Relations: A Necessary Point of Departure}

In 1846, the free trade winds blowing in Great Britain led to the unilateral decision of eliminating wheat and other products from her North American provinces to access the British market, ${ }^{12}$ a heavy blow to the BritishCanadian merchants who had long benefited from the great advantages of having Canadian staple industry consigned for England. ${ }^{13} \mathrm{~A}$ few years later, in 1865, the United States administration of Andrew Johnson announced the abrogation of the Elgin-Marcy ${ }^{14}$ treaty of commercial reciprocity between the British North American provinces and the United States. In response, the Canadian founding fathers sought to find more markets in anticipation of Confederation by sending a trade mission to the Caribbean, which visited Cuba on 17 March 1866, still under Spanish colonial rule but increasingly developing commercial and socio-cultural ties with the United States.

There is plenty of evidence of efforts that were encouraged by representatives of the ruling elites of Canada to promote trade and even to compete with the United States for markets in the Spanish West Indies. The intention was made clear to the Spanish authorities in a letter signed after the meetings in Havana and delivered in person by a trade commissioner to the intendente in Cadiz:

But is it prudent, is it wise, for Spain to allow her rich West Indian possessions to remain wholly dependent for many necessaries on a single source of supply, and the source is the United States ... will it- 
not be a sound policy to encourage and foster a competing source of supply in British North America, the provinces of which when united in one government as it is now contemplated, will form from the outset a confederation of about 4 million people, well qualified to establish in the continent of North America a check and counterpoise to the aggressive and absorbing principle which seems to animate the democracy of the United States. ${ }^{15}$

The statement reflects an important divergence in terms of foreign policy projection by establishing a clear difference between British North America and its southern neighbour, whose foreign projection was by then defined by the Monroe Doctrine.

There were other subsequent attempts to establish commercial linkages and open up markets since the early years of the Dominion to which the same triangular rationale may be applied. As early as 1876, Prime Minister Alexander Mackenzie wrote to Sir Alexander T. Galt, former finance minister and ambassador at large: "I have been informed that you intend to visit part of the West Indies soon; I have long thought that we could extend our commerce to that region ... Trade with Cuba and Saint Domingue is due to its magnitude more important than the rest of the islands." 16 Again, the desire of finding new markets for the export-oriented economy of the Dominion is clearly expressed at a point when the United States was asserting economic control over Cuba and the rest of the Caribbean islands.

With the transfer of colonial hegemony of Cuba from Spain to the United States as a result of a quick inter-imperialist conflict, the new United States occupation government (1899-1902) promulgated a series of decrees that allowed for the chartering of foreign banks.

Canadian banks and insurance companies ${ }^{17}$ were quick to establish solid operations in Cuba that were to guarantee them an important presence in Cuba's economy previous to 1959; the Royal Bank was the most successful. By 1923, the Royal Bank had come into possession of at least 16 sugar mills and 300 acres of fertile sugar cane growing land. The World Bank report listed the Royal Bank number one among all commercial banks in total deposits. ${ }^{18}$

A brief historical overview of the bilateral relations of both North American countries with Cuba would result in identifying a number of fundamental differences in term of the nature, extent, and closeness each actor - Canada and the United States - had with Cuba in the years prior to 1959. For Canada, Cuba policy was undoubtedly less central to its overall foreign policy agenda than the island had been all along for the United States. The Canada-Cuba relationship had been primarily based on trade since the mid-18th century. Nevertheless, it is an obvious fact that Canada had never approximated the degree of involvement the Unites States achieved in its relations with $\mathrm{Cuba}^{19}$ due, in most part, to the almost 
impregnable fortress that was the neo-colonial relationship the former erected around the island, especially after the early years of the 20th century.

Canada's potential trade with Cuba was certainly affected by that neo-colonial relationship that the United States had imposed upon Cuba since 1902 with the consent of the Cuban ruling elites. The Platt amendment and, most significantly in terms of trade, the signing of the US-Cuba Reciprocity Treaty of 1902 were the main instruments of Cuba's neo-colonial status. ${ }^{20}$

An early instance of conflict between Canada and the United States over Cuba trade occurred in 1917, when Canada promised to take nearly double their sugar quota provided that the Cuban authorities could get American approval. The US response by then food administrator Herbert Hoover was to send a letter to the British food controller in London that forced Canada to withdraw its bid for the Cuban market. Subsequently, both Liberal and Conservative governments remained somewhat distant from any involvement in Cuba's political affairs, which were overwhelmingly centred on US-Cuba relations.

The year 1959 ushered in a new scenario in Canada-Cuba relations, notwithstanding the fact that the first year of the Cuban Revolution showed noticeably little change because Cuba's socio-economic structure remained basically intact despite some initial confrontation over the issue of agrarian reform and the political transformations that were taking place. During 1959 Cuba's foreign trade remained mainly centred on US imports and exports.

The next year elicited unprecedented interest in Canada over the question of the treatment accorded to Canadian businesses in Cuba, as the US government began to gradually impose the economic embargo and severed its political and diplomatic ties with Havana; Canadian companies then appeared as an option to fill the void left by US companies that had dominated the Cuban economy. At the same time, the top leadership of the new revolutionary government was trying to preserve and expand its economic links with Canada, as it became an obvious fact that Canada was then in a unique position to provide for the much-needed manufactured commodities and spare parts that Cuba could not acquire from its regular, US suppliers. In many ways, Canadian companies had the same technology and standards as US subsidiaries, as the then Cuban ambassador in Ottawa, Américo Cruz, notes in a report to Cuba's Minister of Foreign Affairs Raul Roa: "In terms of economic relations they [Canada] have a situation similar to what we had previous to 1959."21 Obviously, Ambassador Cruz was referring to the degree of economic interdependence between Canada and the United States compared to the level of dependence the Cuban economy had on the United States. 
In the context of the export-oriented Canadian economy, Canadian companies, especially those in the job-generating manufacturing sector, could gain access to the Cuban market, which had been dominated by the United States corporations since the second half of the 19th century. However, US efforts to prevent Canada from taking advantage of that opportunity, mostly by way of political and diplomatic pressure, and Canada's reticence to go along provoked tension in the bilateral relation.

One important fact in understanding the volume of trade and the possibilities of opening up Canadian business in Cuba is that despite the growing tensions between Washington and Havana during 1959, American companies exported US\$436 million in products and spare parts to Cuba, $\$ 26.2$ million in automobile parts, \$27.3 million in electrical, and over \$18 million in industrial machinery.

Table 1. U.S.-Cuba, Canada-Cuba commercial exchange compared

\begin{tabular}{|c|c|c|l|l|}
\hline & \multicolumn{2}{|c|}{ US Business with Cuba } & \multicolumn{1}{c|}{ Canadian Business with Cuba } \\
\hline Years & $\begin{array}{c}\text { United States } \\
\text { sold in millions } \\
(\$)\end{array}$ & $\begin{array}{c}\text { United States } \\
\text { bought in millions } \\
(\$)\end{array}$ & $\begin{array}{c}\text { Canada sold in } \\
\text { millions (\$) }\end{array}$ & $\begin{array}{l}\text { Canada bought } \\
\text { in millions (\$) }\end{array}$ \\
\hline 1955 & 458.47 & 421.65 & 13.91 & 10.02 \\
\hline 1956 & 519.13 & 457.09 & 15,37 & 12,28 \\
\hline 1957 & 617.98 & 481.86 & 16,89 & 13,87 \\
\hline 1958 & 546.20 & 523.98 & 17,59 & 18,88 \\
\hline 1959 & 436.70 & 474.36 & 15,25 & 12,04 \\
\hline $\begin{array}{l}\text { Cuba looked to United States for some 80\% of its imports of food, machinery, } \\
\text { chemicals, raw materials, and thousands of otheritems required by a nation that } \\
\text { was a net importer of foodstuffs. In return, Cuba sold during a half-century } \\
\text { period at least 70\% of its exports of sugar, tobacco, and other products to the } \\
\text { United States. }\end{array}$ \\
\hline
\end{tabular}

Source: The Financial Post, 29 October 1960.

\section{US and Canadian Reactions to Early Cuban Government Action}

At the same time, the efforts of the Cuban government to transform its neo-colonial condition that made it dependent on the United States naturally met the opposition of the latter, which was the main beneficiary of such status. The main sectors of the Cuban economy were basically under the control of American corporations. From the perspective of the American ruling elite, cutting off trade would render Cuba unable to function.

As early as 21 January 1959 , the idea of imposing economic sanctions on Cuba was part of the rhetoric of US government officials. ${ }^{22}$ The first action that prompted an American reaction to the new Cuban government was the 
Agrarian Reform of 17 May 1959, which was basically in accordance with the Cuban constitution of 1940, a long overdue action that was aimed at transforming the pattern of land tenure on the island. ${ }^{23}$ The reaction of the United States government was, on 12 June 1959, to demand prompt, adequate, and effective compensation. This demand was not in accordance with international law: the accepted practice since 1938 was that of compensation as agreed upon by the parties involved. ${ }^{24}$ Therefore, from the Cuban perspective, the nationalizations were a sovereign act in the national interest. Moreover, the Cuban state was literally unable to afford the compensation payments due to lack of co-operation on the part of the United States government. ${ }^{25}$

Cuba's national action and lack of compliance in returning US-owned property ${ }^{26}$ led to the first of several proclamations directed against trade with the revolutionary government. On 19 October 1960, President Eisenhower authorized the secretary of commerce to place Cuba on the US Export Control List, thereby cutting off all exports to the island except non-subsidized foodstuff, medicines, and medical supplies. In President Eisenhower's words, "[if] the Cuban people got hungry enough they would throw Castro out."27

The United States government did inform its Canadian counterpart of the action it was about to take and of how Canadian subsidiaries would be affected. However, there are a few aspects that must be reviewed in order to have a clear understanding of the events that were to unfold as well as Canada's relation to it.

The United States Export Control Act of 1949 established an Office of Export Control in the Department of Commerce, which had the authority to prohibit the exportation from the United States of "all commodities and technical data" unless a general license granting such permission was issued by the Office. All foreign countries, as potential importers, were classified into groups, each group being subject to differing degrees of control, with the Communist states subject to the severest controls. Within this category, a tripartite subdivision existed: Soviet-bloc states in one category, Cuba in another, and China, North Korea, and North Vietnam comprising the third, in increasing order of regulatory control.

It is crucial to point out that Canada was alone in that it was exempted from the above process of classification. The United States permitted the unregulated export of nearly all commodities and technology of American origin ifCanada remained the final destination of consumption or use. First, the re-exportation of all goods originating outside Canada (i.e., overwhelmingly American goods) required an export permit. Second, the Canadian government regulated its own export trade under the authority of the Export and Import Permits Act and the Area Control List, which was modelled after the secret COCOM (Coordinating Committee for 
Multilateral Export Control) List of NATO, which banned the traffic of a wide variety of goods classified as "strategic."

In view of these interrelationships, it is difficult to see how the imposition of American economic controls could not directly affect Canada-Cuba trade and, for that matter, Canadian sovereignty. It is against this backdrop that the United States' unilateral embargo was placed.

The repercussions of the US unilateral actions toward Cuba were to be felt in all the countries to the West in general, and within the NATO alliance states as well as in Latin American countries, thus generating other triangular relations as the United States government sought to isolate Cuba. However, the case of Canada deserves to be singled out due to the nature of the relation - that is, the growing economic, political, and military interconnectedness of Canada and the United States in the post-Second World War world. This development, since 1960, served to spotlight public attention on the issue of the US extraterritorial laws, which often regulated the export policies of Canadian subsidiaries. Moreover, it called into question the scope of American economic, political, and, for that matter, military penetration of Canada. However, of all the foreign assets and non-Cuban capital stock appropriated by eminent domain or expropriated without immediate compensation by the new Cuban government, none was treated more selectively, and for that matter more diplomatically, than Canadian enterprises and nationals.

Cuban-Canadian companies were excluded from the initial nationalization decrees of the Cuban government. Canadian companies were treated according to the rules of international law, and although Canada-Cuba bilateral relations were also affected by disputes, the way they were settled shows a distinct pattern, notwithstanding the fact that Canadian interests in Cuba were somewhat limited to specific areas.

On 1 July 1960, in its first major act of expropriation, the Cuban government peacefully seized all of the plant equipment and property of the Standard Oil of New Jersey, Texaco, and Shell Petroleum companies in Cuba. The seizures were in direct response to the refusal of the three subsidiaries to refine shipments of lower-priced Soviet crude oil, which began arriving on the island parting compliance with the USSR-Cuba Oil Agreement, signed on 1 April 1960 during the visit of Anastas Mikoyan, Soviet foreign minister to Havana.

This initial expropriation proved to be of direct concern to certain Canadian interests, for it was disclosed immediately after that Shell de Cuba's marketing operations were overseen by the Shell Oil Co. of Canada, the largest oil manufacturer in the country, which was incorporated in Canada as a "holding company" under the rubric of Canadian Shell Ltd., limiting its de jure Canadian status. ${ }^{28}$ 
A new wave of nationalization edicts were promulgated several months later, on 13 and 14 October. The decrees placed 382 Cuban and foreignowned businesses, with an estimated value of US\$2 billion in total assets, under both state ownership and state control for the first time. The entire trade sector of the economy was nationalized, as well as all banking establishments on the island except two: the 24 branches of the Royal Bank and the eight branches of the Bank of Nova Scotia.

The reasons of the new government of Cuba for exempting the Canadian banks from the October decrees have been the subject of a good deal of speculation. One widely accepted hypothesis suggests that the government sought to keep at least one banking channel to the free currency exchange market. Canadian banks, as in the case of the potential purchase of spare parts and manufactured goods, were in the best position because of their long-standing involvement in Cuban banking affairs and their connections with the United States, geographically as well as financially.

For Ottawa, that pattern of exceptional treatment accorded to Canadian companies and nationals was one reason for maintaining a completely different approach toward its relations with Cuba than that of the United States: "The United States' authorities expressed that the economic measures taken by the Cuban government against the interests of the United States and its citizens are arbitrary, illegal and discriminatory, so that it requires of an embargo against Cuba. Canada does not justify an embargo or

- similar measures because the treatment of the interests of Canada and that of its citizens has been different."29

\section{The Cuba Trade Debate and Increased Triangular Tension}

Once economic ties between Cuba and the United States were finally severed on 19 October 1960 when the US trade embargo was put in place by the Eisenhower administration, one of the first actions of the revolutionary government in Cuba was to turn to Canada. The debate over Cuban trade, both domestically in Canada and in terms of Canada-US relations, reached its highest point with the visit, on 8 December 1960 , of a Cuban commercial delegation seeking to increase imports from Canada, headed by then Minister of the Economy Regino Boti. ${ }^{30}$ The Canadian government's reaction after their initial surprise was summed up in a statement by Canada's minister for international trade, George Hees: "Canada would be willing to sell the products that $\mathrm{Cuba}$ is unable to acquire as a result of the US embargo." $" 31$

That statement was welcomed in both Ottawa and Havana.because there were clear advantages for both, but it was a great source of dismay for Washington. The advantage for Canada was that the United States was "rapidly disengaging from the Cuban market." ${ }^{32}$ Canada could obtain large economic gains at Washington's expense just by filling the ensuing trade 
void, particularly in the sale of manufactured goods and spare parts. To Cuba, Canada appeared the short-term natural substitute for trade due to its geographical proximity, as opposed to Europe, to its close relations with the United States, and to the fact that Canadian companies who were in many cases branch plants of US companies and had basically the same technology.

Canadian nationalism and its relations with the United States received extraordinary attention in the media, which raised more fundamental questions regarding Canadian independence. Given the role of the media in shaping public debate, a small sample of headlines appearing on influential Canadian dailies show some of the viewpoints held by the public, which had an impact on the Canadian foreign policy-making process. In 1960, the Financial Post wrote, "Castro says Canadians Very Welcome." 33 In October, as the debate over trade raged on, the same paper wrote, "Can We Do Business with Castro's Cuba?"34

The 1960 Canadian Annual Review asserts that a high official of the United States Department of Commerce had endeavoured to enlist Canada's support for the enforcement of the October embargo on 11 December 1960, but that the attempt had been "without success." This is substantiated by a headline that appeared on the following day in the Globe and Mail, which stated that Secretary of State Herter "failed to get Canada to co-operate in the United States' economic squeeze against Cuba ... which includes, from the United States' point of view, a ban on strategic exports to the recalcitrant island dictatorship." 35

The article goes on to say that Bradley Fisk, assistant secretary of commerce for international affairs (the US "high official" mentioned above), said that efforts to obtain such support "would continue." When asked whether specific pressures might be brought to bear on the Canadian government or Canadian industry, Fisk was quoted as saying, "No action is contemplated - we will respect Canada's sovereignty in every way, but we will keep reminding Canada of our mutual fight against Communism." 36

\section{Canada's Response to the US Commercial Embargo against Cuba}

The government of Prime Minister John Diefenbaker expressed its opposition to the United States commercial blockade against Cuba in a speech to the House of Commons on 12 December 12 1960:"We respect the other nation's opinions as to their relations with $\mathrm{Cuba}$ as much as we expect that our points of view be respected. Canada reserves the right to trade with any country, including Cuba, and any commodity it so pleases." ${ }^{37}$ This statement represents a clear allusion to the United States' pressures on Canada to break its traditional commercial ties with Cuba and join the embargo against the island. At the same time, it highlights once again the 
Canadian government's divergent position regarding its relationship with Cuba.

Washington's continuing pressure on Canada and the evolution of the situation in Cuba in the context of the Cold War drove the Canadian government to define Canada-Cuba trade policy. On 23 December 1960, Diefenbaker issued the following statement:

1) No shipment of arms, ammunition, military and related equipment, or materials of clearly strategic nature will be or has been licensed for export from Canada to Cuba for more than a year. This course is based on the Government's general policy of refraining from exporting such goods or commodities. to areas of tension anywhere in the world.

2) A tight control is exercised on the export of goods such as aircraft engines, which may in certain circumstances have strategic significance. Individual exports permits are required in each case and, as applications are received, the circumstances determine whether the export of the goods concerned has a strategic significance, and if not a permit is issued.

3) As to Canadian goods of a non-strategic nature, there are no limitations on such trade with Cuba. ${ }^{38}$

The issued statement highlighted once again the desire of the Canadian government to maintain the bilateral commercial relationship with the Cuban revolutionary government, and defined its position toward the United States' commercial embargo against Cuba. Moreover, this document represents a brief summary of the main aspects of Canadian foreign policy in general.

Canada's decision to not export arms, ammunition, military, or related equipment - that is, strategic goods - to Cuba was consistent, for it is Canada's general policy to not sell strategic goods to areas of tension in the world. However, as outlined in the points above, the Canadian government did not impose any limitations as to the trade of non-strategic goods with the island. Ottawa felt capable of following its own chosen path, but it was also present in the minds of Canadian policy-makers that the United States was Canada's political ally as well as its biggest commercial partner. Canada looked for a multilateral approach and sought support from other countries, members of NATO and allies of the United States, to follow a divergent path to that of a trade embargo on Cuba. Cuba became a point of disagreement between both countries.

Ottawa's policy-makers strongly expressed their concern that the US embargo would have the effect of driving Cuba into the Soviet camp. Thus, there was a belief that it was up to countries like Canada and the United 
Kingdom ${ }^{39}$ to do what they could in order to maintain the links with Havana. The concern about the US policy toward Cuba is well reflected here: "We do not minimize American concern, but it is the Government's view that to maintain mutually beneficial economic relations with Cuba may help and contribute to the restoration of traditional relationships between Cuba and the Western world." 40

While there is plenty of evidence that by 1961 the Canadian government was convinced that Cuba was a Communist country and that it found some of Cuba's actions deplorable, that did not constitute a reason for departing from normal relations. This position was also consistent; Canada had developed a commercial relationship with the People's Republic of China, which was then considered a strong part of the Communist Sino-Soviet alliance.

One last element to support Canada's divergent position was that the balance of trade with Cuba showed that Canada maintained a trade surplus from 1959 to 1964.

Table 2. Canada Cuba Trade Balance

\begin{tabular}{||r|r|r|r|}
\hline \hline Year & $\begin{array}{c}\text { Canadian Imports from } \\
\text { Cuba (CANS) }\end{array}$ & $\begin{array}{c}\text { Canadian Exports to } \\
\text { Cuba (CAN\$) }\end{array}$ & Trade Balance (CAN\$) \\
\hline 1957 & 13,840 & 16,846 & 3,006 \\
\hline 1958 & 18,836 & 17,549 & $(1,287)$ \\
\hline 1959 & 12,011 & 15,222 & 3,211 \\
\hline 1960 & 7,243 & 13,038 & 5,795 \\
\hline 1961 & 5,034 & 31,104 & 26,070 \\
\hline 1962 & 2,803 & 10,878 & 8,075 \\
\hline 1963 & 13,041 & 16,433 & 3,392 \\
\hline 1964 & 3,464 & 60,930 & 57,466 \\
\hline
\end{tabular}

Source: Statistics Canada, Canada 1958-1965 Yearbook

Naturally, Canada was taking advantage of the situation and siphoning the already scarce foreign exchange of Cuba. That fact was acknowledged in a statement on CBC-TV shortly after the Canada's participation as an observer at the Organization of American States conference in Punta del Este, Uruguay: "It should be recalled also that trade with Cuba in non-strategic goods runs heavily in favor of Canada so there can be no possibility of earnings by Cuba on her exports to Canada being used, as has been suggested by the press to promote communist subversion in neighboring countries. On the contrary, Cuban trade with Canada is absorbing dollars secured from other sources." 41 The Canadian prime minister cautioned, "Embargoes and trade controls are powerful and sometimes double-edged weapons. If we use them towards Cuba we may be 
under pressure to use them elsewhere and unnecessary damage will be done to Canadian trade." 42 Diefenbaker also maintained that isolating the island from Western trade and diplomatic contact would instead drive it to further reliance on less desirable associations. ${ }^{43}$

The Canadian government continuously rejected the pressures from both the Eisenhower and Kennedy administrations to support American attempts to isolate Cuba. The years 1961-1962 would prove to be a more complex period for the triangular relationship as issues other than trade came into play in the context of the Cold War. An increased US effort to bring about a change of regime in Cuba combined economic isolation with diplomatic, military, and subversive components.

\section{Cuba's Reaction to United States Policy and its Impact on the Canada-Cuba Relationship}

On 16 January 1961, then Cuban ambassador in Ottawa Américo Cruz wrote in a report to his minister, after having met with Mr. Howard Green, then Canadian Minister of Foreign Relations, "The minister told me that they had to maintain cordial relations with the United States, but it continues to be a principle of their foreign policy and trade policy to maintain Canadian independence. However, he told me that we must not forget the situation in which they are in relation to the United States." $\$ 4$

The Cuban revolutionary government gave a fair assessment of the Canadian government's position, as well as of the potential impact of US responses in terms of political rhetoric and action since the early months of the Revolution. Such a position is reflected in the following excerpt from a letter from the Cuban Ministry of Foreign Affairs to its ambassador in Ottawa: "We call your attention upon the fact that the resistance provided by the government of Canada, up to now, to the United States' continuing pressures, aimed at forcing Canada to join the blockade of Cuba, must not be underestimated." 45 In this message and in subsequent communication with the Cuban ambassador, the Cuban foreign ministry urged the Cuban ambassador to use all the tools of the diplomatic arsenal to safeguard the interests of maintaining a positive relationship with Canada despite the fundamental ideological differences that separated both governments: "The best thing to do is to work harder in terms of confidence building actions that would strengthen the relation between Canada and Cuba." 46

\section{The Political and Diplomatic Dimension in the Triangular Relationship}

On the diplomatic and political front, Canada formally announced recognition of the new Cuban government on 8 January 1959, the day the rebel army entered Havana and one day after the United States accorded similar treatment. It was Canada's minister of foreign relations, Sydney 
Smith, who gave instructions to its ambassador in Cuba to "confirm the desire of the Canadian government to maintain friendly relations with the Cuban Revolutionary government." ${ }^{.47}$ The position of granting official recognition to the Cuban revolutionary government is in accordance with a traditional tenet of Canadian foreign policy, as Prime Minister John Diefenbaker writes in his memoirs: "Our interaction is guided by the international rules that exist between two sovereign nations. It was Canada's duty to maintain with Cuba the cordial relations customary with the recognized government of another country. ${ }^{\circ 8}$ Canada's conservative government was to maintain its diplomatic recognition of the new Cuban government. However, the relationship was not to be free of contradictions, for there were political, ideological, and security issues involved.

At the political level, there were obvious differences between the Canadian and the American approach to Cuba. On 12-14 July 1960, in Montebello, Quebec, at a conference to discuss defence issues, Cuba was discussed, having been brought up by the United States' delegation as requested by President Eisenhower himself in a note to his Canadian counterpart. After describing the actions of the Cuban government as unreasonable and provocative and inviting Soviet penetration into the western hemispheres, he went on to say, "I thought it might be useful for Secretary Herter to discuss the question with Mr. Howard Green when they meet in Ottawa this coming week[.] I would be most grateful if the views of your government about this tragic situation would be made known by $\mathrm{Mr}$. Green to Mr. Herter in that meeting." ${ }^{49} \mathrm{Mr}$. Green did convey the Canadian position, as H. Basil Robinson comments in his book Diefenbaker's World: A Populist in Foreign Affairs: "The Canadians spoke with such frankness and resolve that the Americans were stunned at the differences of their analysis from that of the Canadians." 50

There was indeed profound divergence between the United States and the Canadian approach to the political relationship with $\mathrm{Cuba}$, and it was marked by the distinct Canadian view that the causes of the Cuban revolution were indigenous rather than the result of a Communist expansion in the western hemisphere. Diefenbaker would later confirm this in his statement of 23 December 1960. From that moment on, Cuba would be a point of friction between the two neighbours and allies, along with the issue of nuclear weapons, for it became obvious that Washington had mistakenly taken for granted Ottawa's support in its policy of isolating Cuba. In fact, during the earliest years of the Cuban Revolution, the use of diplomatic pressures constituted the principal modus operandi of both Eisenhower and later the Kennedy administrations. 


\section{The Defence and Security Dimension of the Triangular Relationship}

The aspects of defence and security are very important in foreign policy. They become even more relevant in this case when one looks at the Canadian and American defence relationship against the backdrop of the Cold War. Since the Cuban government had been classified as a Communist country the positions of both Canada and the United States would converge to a great extent.

As early as 1938, President Roosevelt and Prime Minister Mackenzie King had expressed mutual commitments toward co-operative defence; two years later the Ogdensburg Treaty (1940) was signed, the Joint Board on Defence was created, and a year later the Hyde Park agreement extended the provisions of the Lend-Lease Act for British purchases of weapons. During the Second World War years, there existed full a partnership, which began after the Japanese attack on Pearl Harbour on 7 December 1941, although Canada's commonwealth connection made Canadian forces stay away from the Pacific theatre of operations, where the United Stated concentrated its war effort before June 1944.

The end of the war brought abouta new world order in which Canada and the United States were founding members of NATO. Both North American nations would co-operate during the Korean War and later increase their defence integration with the creation of the North American Air Defense Command. There has been increased naval co-operation and intelligence sharing ever since.

In terms of Cuba policy before 1959 , there was no divergence between Canada and the United States on the issue of the export of military equipment to Cuba, since right up to March 1958, the United States would supply all arms requirements to Cuba. However, in March 1958, the Eisenhower administration suspended all supplies of arms to Cuba as rebel actions increased. The Cuban government of Fulgencio Batista turned to Canada to purchase airplanes and ammunitions. The Canadian government turned down all requests.

After the triumph of the revolution of 1959 , Canada was caught in the dilemma of fulfilling its obligation as a NATO and NORAD member in the context of the Cold War. The issue of the sales of weapons and any kind of material considered strategic according to a NATO classification was forbidden. In this sense, the Canadian authorities fully co-operated with their American counterpart. On this matter, Prime Minister Diefenbaker's statement made in the House of Commons on 12 December 1960 will provide more details:

We have not for some time permitted the export of arms, munitions and closely related goods to ... Cuba ... 
With respect to other goods of Canadian origin, there can be no valid objection to trade with Cuba as with other countries. The businessmen concerned will have to make their own judgments on the prospects for advantageous transactions.

It is our wish, consistent with our relations with other countries, to maintain the kind of relation with Cuba, which is usual with the recognized government of another country. It is, of course, not our purpose to exploit the situation and we have no. intention of encouraging what in effect would amount to the bootlegging of goods of United States origin. ${ }^{51}$

Convergence with the United States is here expressed in the form of official co-operation, not only in the questions of strategic material, but also in terms of the re-exportation of American goods. Canadian authorities repeatedly searched Cuban vessels to enforce such policy.

In fact, perusal of the Control List will reveal that many items classified as "strategic" have little or no direct military use. Moreover, Diefenbaker was to later disclose in the House of Commons, during the Bay of Pigs Invasion, "no export of military equipment and related goods has been authorized for sale to the entire Caribbean region since July of 1959." Yet the 28 December 1960 issue of the Canada Gazette contained an amendment, which regulated Canadian trade with specified (i.e., Communist) countries, adding Cuba to these countries. ${ }^{52}$

Hence, by this addition, Cuba had become "communist" in the eyes of the Canadian state, and thereafter trade with her was to be under surveillance and control, conforming substantially to American, and presumably NATO, regulations. This is even clearer in a statement made by the prime minister soon after the Bay of Pigs Invasion, on 19 April 1961, 53 when he expressed his government's "deep concern over developments in Cuba and characterized Cuba as a bridgehead of international communism threatening the hemisphere, a danger to which Canada could not be indifferent." In a subsequent statement on hemisphere and global problems on July 1961, he stated, "The Canadian Government is as concerned as any government over the Communistic trends of the Cuban Government. ${ }^{54}$ Nevertheless, in terms of foreign policy, Canadian Cuba policy continued to diverge from that of the United States. The two countries held divergent approaches in ballistic missile defence and nuclear weapons, despite the fact that there was an indirect threat to Canadian security due to Canada's geographic position just beneath the shortest air route between the continental United States and the then USSR.

There is no more dramatic event in the history of the Cold War than the Cuban Missile Crisis, when the United States and the Soviet Union came to the brink of a nuclear confrontation that would have been the most devastating conflict in human history. The event in itself has been the object 
of numerous international conferences, books, and films. In most, with the notable exception of Peter Haydon's important contribution, ${ }^{55}$ the role of Canada tends to be minimized, as is the role of Cuba. One aspect relevant to the main argument of this article is that the missile crisis was a time of a crisis in Canada-US relations due to, among other things, the divergent view of Prime Minister Diefenbaker on how to deal with the situation and to which extent Canada had to be involved. As Peter Haydon reminds us, "One of the problems within the Canadian response to the Cuban missile crisis was the very different perception of its nature and implications. ${ }^{56} \mathrm{On}$ the other hand, due to the intricate interconnection of Canadian and US military, the Canadian Navy's participation in the events must not be underestimated.

The United States and Canadian governments would also co-operate intensively in the field of intelligence. Through the Canadian embassy in Havana, the Canadian government provided intelligence on Cuba on a regular basis to the United States and other allies during the early years of the Cuban Revolution. According to Professor Don Munton of the University of Northern British Columbia, Canadian diplomats would be sent out to collect intelligence on military installations and other things in Cuba important to the Americans. In October 1962, Canadian embassy officials reported on the initial preparations for the installations of missiles in Cuba. Minutes of high-level meetings between Canadian and Cuban officials were also made available to US Intelligence.

\section{Conclusion}

While the relationship between Canada and the United States has historically been close, their divergence stems from the founding principles upon which both nations emerged as independent states and the place they have occupied within the international system. The Canadian state, due in part to the challenges of the geographical, economic, and defence and security reality, has favoured multilateralism and "middlepowermanship" in its dealings with the United States. The issue of Cuba policy after 1959 has been especially complex due to the nature and dynamics of Canada-US and Cuba-US relations. The actions and reactions of all three actors involved in the triangle during the first years following the triumph of the Cuban Revolution have set the tone for the years to come with striking regularity.

The end of the Cold War brought about very important changes in the international system. The bipolar world ended, the United States emerged as the sole super power determined to extend neo-liberalism to the remotest corners of the globe by benefiting from the advantages of the objective process of globalization. 
In that context, it is fair to assert that the relationship between Cuba and the Unites States has continued to be characterized by Cold War-style confrontation, since the Cuban state has stayed the nationalist course set after 1959 and the United States has increased its efforts to bring about the end of the Cuban government. The American policy is almost exclusively designed by and constructed on the basis of information provided by the right-wing sector of the Cuban-American community in South Florida. On the other hand, Canada-Cuba policy has continued to stress engagement, trade, and political dialogue despite ideological disagreement. From the Conservative John Diefenbaker during the hottest period of the Cold War to the Liberal Jean Chrétien in the early years of the post-Cold War 1990s to the current Conservative government of Canada in the first decade of the 21 st century, successive Canadian governments have maintained trade relations, diplomatic engagement, and political dialogue, with highs and lows, with Cuba over the last 49 years. Canada has indeed been more tolerant of ideological pluralism in other countries than the United States.

The United States and Canada will continue to converge in many aspects of their foreign policy, as well, especially on the need to extend the Western pattern of civilization all over the world, and especially in the western hemisphere. The objective process of globalization has reinforced the condition of complex interdependence that characterizes the bilateral relationship between the North American neighbours. Consequently, their economies may continue along the path of deeper integration and the consolidation of the continentalist trend, the post-9/11 United States security concerns may lead to even greater co-operation and harmonization in terms of defence and security, and both countries will hold responsibility for a shared environment. However, the two North American nations will also continue to diverge, especially in terms of the means to pursue their own foreign policy agenda, as the last 49 years of Cuba policy have shown.

\section{Notes}

1. Morris H. Morley, "The United States, and the Global Economic Blockade of Cuba: A Study in Political Pressures on Americas Allies," Canadian Journal of Political Science/Rèvue canadienne de science politique 17, 1 (1984): 25-48.

2. Many authors have tried to explain the nature of Canadian-American relations. Most agree on the fact that it is a unique type of relation. An excellent description of the relationship between Canada and the United States is provided by Jack Granatstein in his article "Cooperation and Conflict: The Course of Canadian American Relations since 1945," in Canada and the United States: Enduring Friendship, Persistent Stress, Charles F. Doran and John S. Sigler, eds., 45-68 (Englewood Cliffs, NJ: Prentice-Hall, 1985).

3. The Royal Bank of Canada and the Bank of Nova Scotia, which operated 23 and 8 branches respectively, represented direct Canadian investment in Cuba. There were five insurance companies: Confederation Life, Sun Life, Crown, Imperial, and Manufacturer's life insurance companies. The Western Assurance Company was the only Canadian company writing marine, fire, and general insurance in 
Cuba; other investments were represented by the minor participation in the mining and petroleum exploration. The overall investments were estimated around US\$20 million.

4. For conceptual reference see Robert Keohane, and Joseph Nye, "Power and Interdependence Revisited," International Organization 41, 4 (1987): 725-53.

5. Sahadeo Basdeo, and Heather Nichols, eds. Canada, the United States and Cuba: An Evolving Relationship. (Coral Gables: North-South Center Press, 2002).

6. Seymour Martin Lipset, Continental Divide: The Values and Institutions of the United States and Canada (New York: Routledge, 1990). 8

7. Michael Adams, Fire and Ice: The United States, Canada and the Myth of Converging Values (Toronto: Penguin Canada, 2003). 5, 6, 7.

8. Robert Bothwell, Canada and the United States: The Politics of Partnership. Twayne International History Series (New York: Macmillan, 1992), 3.

9. John W. Holmes, "Canada and the United States in World Politics," Foreign Affairs 40, 1 (1961): 106.

10. The Moncada program became the platform of the 26 July Movement (M-26-7) and took its name after the Moncada military garrison that was attacked on 26 July 1953 by a group led by Fidel Castro.

11. Secret Briefing Memorandum, Canada-US Relations and Cuba. U.S. National Archives. RG 59, Alpha Numeric Files Referring to Canadian Affairs, 1957-1963.

12. Michael Hart, "The Road to Free Trade," in Free Trade: Risks and Rewards, ed. L. Ian MacDonald (Montreal and Kingston: McGill-Queen's University Press, 2000).

13. Donald Creighton, The Commercial Empire of the St Lawrence: 1760-1850 (Toronto: Ryerson Press, 1937).

14. For an excellent study on this period see James M. Callahan, American Foreign Policy in Canadian Relations (New York: McMillan, 1927).

15. Report of the Commissioners Fram British North America Appointed to Enquire into the Trade of the West Indies, Mexico and Brazil, quoted in Harold Boyer, "Canada and the Cuban Revolution: A Study in International Relations" (PhD dissertation, University of British Columbia, 1972).

16. Oscar D. Skelton, The Life and Times of Sir Alexander Tilloch Galt (Toronto: Oxford University Press, 1920).

17. During the first decade of the Republic, two banks and two insurance companies had been incorporated into Cuba. In 1899, the Royal Bank, the Bank of Nova Scotia in 1906, and Sun Life Assurance Co. in 1907, followed by Confederation Life, followed the Merchant Bank of Halifax.

18. Francis Truslow, et al. Report on Cuba, International Bank for Reconstruction and Development (Washington, DC, 1951).

19. The exception to the rule are the Canadian banks and insurance companies that operated in Cuba from 1899 until the early years of the Revolution. Other than that, Cuba's foreign trade was overwhelmingly conducted with the United States. For more information on the role of the Royal Bank in Cuba, see Charles Edward Chapman, A History of the Cuban Republic: A Study in Hispanic American Politics (New York: Macmillan Company, 1927).

20. For a comparison between US and Canadian trade with Cuba prior to 1959 , see Tables 1 (p. 123) and 2 (p. 129).

21. Américo Cruz, Cuban Ambassador to Canada to Cuban Minister of External Relations, Raul Roa, 16 January 1961, Ministerio de Relaciones Exteriores Archivos, Havana, Cuba. 
22. US representative Wayne Hays stated that economic sanctions must be considered, especially the reduction of the sugar quota and a trade embargo.

Cuba U.S government on trail "The Guardian", Wednesday, March 1, 2000. http://www.agitprop.org.au/stopnato/20000302cubaoguard.php.

23. The Cuban constitution of 1940 proscribed latifundia (pieces of property covering large areas); however, up to 1959 no law had been enacted to enforce that provision. Article 24 of the document provided the legal framework for expropriation in the name of national interest.

24. On 3 August 1938 , the Mexican government sent a note to the US government. It is impossible to achieve the transformation of a country, the future of a nation, due to the inability to immediately pay compensation for the value of property belonging to a small number of foreigners whose main interest is the pursuit of profit. Miguel A. D’Estefano Pisan, Derecho Internacional Publico, Editora Universitaria. La Habana, 1965.

25. Over $\$ 470$ million of the Cuban National Bank were taken to the United States by Batista government officials and never returned despite the fact the US had recognized the Cuban government.

26. The Cuban government did not accept the demand of the United States government regarding the nature of compensation.

27. Eisenhower Papers. Memoranda of conferences with the president. Quoted in Trumbull Higgins, The Perfect Failure (New York: W.W. Norton, 1987), 48.

28. Canadian Shell was owned by British Shell (40\%) and Royal Dutch Shell (60\%); both were part of Shell International. No Canadian national owned shares in the company.

29. Jack Ogelsby, "Continuing US Influence on Canada-Cuba Relations," International Perspectives (September-October 1975): 34-38.

30. The Cuban delegation was rather large. It also included the minister of transportation, the director of the Cuba Oil Institute, and the directors of the National Bank and the Commercial Bank.

31. The Diefenbaker Papers. The Diefenbaker Canada Centre, Saskatoon, Saskatchewan.

32. John Kirk, and Peter McKenna, Canada-Cuba Relations: The Other Good Neighbor Policy (Florida: University Press of Florida, 1997), 31.

33. Financial Post, 12 July 1960.

34. Financial Post, 29 October 1960.

35. Globe and Mail, 12 December 1960.

36. Ibid.

37. Prime Minister's Speech to the House of Commons, 12 December 1960. Debates, House of Commons, Session 1960, 61, Volume 1, December 12, 1960. 700

38. Press release: "Trade with Cuba" by the Right Honourable John Diefenbaker, Saskatoon, 23 December 1960. The Diefenbaker Papers.

39. British Prime Minister Harold Macmillan openly supported this position, that isolating Cuba would only drive her closer to the Soviet Union.

40. Ibid.

41. The Diefenbaker Papers.

42. Ibid.

43. These differences in views and the pressures brought to bear against Canada by United States officials were evident, for example, at the July 1960 closed-door meeting of the Canada-United States Ministerial Committee on Joint Defense. See H. Basil Robinson, Diefenbaker's World (Toronto: University of Toronto Press, 1989), 146. 
44. Américo Cruz, Cuban ambassador to Canada to Raul Roa, Cuban Minister of Foreign Affairs, 16 January 1961. Ministerio de Relaciones Exteriores, Archivos, La Habana, Cuba.

45. Carlos Olivares Sanchez, Political Under-Secretary, Ministry of Extemal Relations to Américo Cruz, Cuban Ambassador to Canada, 11 April 1962. Minrex Archivos, La Habana, Cuba.

46. Ibid.

47. Department of External Affairs, Information Division, Canadian Weekly Bulletin 14, 2 (14 January 1959), 6.

48. John Diefenbaker, One Canada: Memoirs of the Right and Honourable John G. Diefenbaker (Toronto: Macmillan of Canada, 1977), 169. Volume 2.

49. Message from President Eisenhower to Prime Minister Diefenbaker, 9 July 1960. The Diefenbaker Papers.

50. Basil H. Robinson, Diefenbaker's World: A Populist in Foreign Affairs (Toronto: University of Toronto Press, 1989), 146.

51. Ibid.

52. Canada Gazette, 28 December 1960.

53. The Canadian government did not support the invasion militarily or politically; however, there was no official statement of condemnation of the act of American intervention on Cuba's internal affairs.

54. Address by Prime Minister John G. Diefenbaker, Kiwanis International - Convention, 3 July 1961, Toronto. The Diefenbaker Papers

55. Peter T. Haydon, The 1962 Cuban Missile Crisis: Canadian Involvement Reconsidered (Toronto: The Canadian Institute of Strategic Studies, 1993).

56. Ibid., 62. 